\title{
Prospects for integrated soil fertility management using organic and inorganic inputs: evidence from smallholder African agricultural systems
}

\author{
Frank Place $^{\mathrm{a}, *}$, Christopher B. Barrett ${ }^{\mathrm{b}}$, H. Ade Freeman ${ }^{\mathrm{c}}$, \\ Joshua J. Ramisch ${ }^{\mathrm{d}}$, Bernard Vanlauwe ${ }^{\mathrm{d}}$ \\ a World Agroforestry Centre, P.O. Box 30677, Nairobi, Kenya \\ b Department of Applied Economics and Management, Cornell University, 315 Warren Hall, Ithaca, \\ NY 14853-7801, USA \\ c International Crops Research Institute for the Semi-Arid Tropics (ICRISAT), P.O. Box 39063, \\ Nairobi, Kenya \\ d Tropical Soil Biology and Fertility Institute (TSBF), International Center for Tropical Agriculture \\ (CIAT), P.O Box 30677, Nairobi, Kenya
}

\begin{abstract}
This paper reviews current organic nutrient management practices and their integration with mineral fertilizers in Sub-Saharan Africa with a view to understanding the potential impacts on a range of input markets. A number of different organic nutrient management practices have been found to be technically and financially beneficial, but they differ considerably as to their effectiveness and resource requirements. A review of African smallholder experiences with integrated soil fertility management practices finds growing use, both indigenously and through participation in agricultural projects. Patterns of use vary considerably across heterogeneous agroecological conditions, communities and households, but are stimulated by profitable commercially oriented agricultural opportunities. The potential for integrated soil fertility management to expand markets for organic inputs, labor, credit, and fertilizer is explored. We found that there are few direct analyses of these links and indirect evidence at this point in time is inconclusive.
\end{abstract}

(C) 2003 Elsevier Ltd. All rights reserved.

Keywords: Nutrient management; Integrated soil fertility management; Inputs; Africa

\footnotetext{
${ }^{*}$ Corresponding author.

E-mail address: f.place@cgiar.org (F. Place).
} 


\section{Introduction}

Soil fertility replenishment in Sub-Saharan Africa (SSA) is increasingly viewed as critical to the process of poverty alleviation; this was symbolized clearly by the award of the 2002 World Food Prize to Pedro Sanchez, a pioneer in the field. Soil fertility is crucial because African poverty is mainly a rural phenomenon and per capita arable land in SSA has shrunk from 0.53 to 0.35 hectares between 1970 and 2000 (FAOSTAT, 2002). ${ }^{1}$ Accelerated and sustainable agricultural intensification is required. Yet intensification, increased agricultural productivity and improved rural livelihoods cannot occur without investment in soil fertility.

African soils exhibit a variety of constraints: physical soil loss from erosion, nutrient deficiency, low organic matter, aluminum and iron toxicity, acidity, crusting, and moisture stress. Some of these constraints occur naturally in tropical soils, but degradation processes related to land management exacerbate them. Estimates suggest that about two-thirds of agricultural land is degraded, with $85 \%$ caused by wind and water erosion (Oldeman et al., 1991).

Limited use of nutrient inputs among smallholder farmers exacerbates soil nutrient deficiency. African fertilizer use was never high, averaging about $9 \mathrm{~kg}$ per hectare by the late 1990s. Viewing all nutrient inputs together does not alter this picture (Henao and Baanante, 2001). The estimated losses, due to erosion, leaching, and crop harvests are sometimes staggering, at over $60-100 \mathrm{~kg}$ of $\mathrm{N}, \mathrm{P}$, and $\mathrm{K}$ per hectare each year in Western and Eastern Africa (e.g. Stoorvogel and Smaling, 1990; de Jager et al., 1998).

Integrated soil fertility management (ISFM) is rapidly becoming more accepted by development and extension programs in SSA, and, most importantly, by smallholder farmers. ISFM is about expanding the choice set of farmers by increasing their awareness of the variety of options available and how they may complement or substitute for one another. To contribute to the theme of this special issue, the major analytical foci of this paper are to examine (1) the complementarities and synergies between organic and mineral nutrient inputs and (2) therefore the potential for such complementarities to increase market activity and demand for purchased agricultural inputs. As background, we describe various organic nutrient sources and present some evidence about their benefits. This is done not to endorse any particular type of nutrient management system but rather to support the subsequent analyses.

This paper first presents evidence on the yield effects of organic nutrient practices and ISFM. A summary of evidence on farmer investment in and management of organic nutrients and ISFM comes next, followed by a synthesis of available evidence on the ability of ISFM systems to foster markets for organic nutrients, mineral fertilizer and other agricultural inputs. Lastly, we conclude the paper with implications for research, design and dissemination of ISFM, and policy reform.

\footnotetext{
${ }^{1}$ This figure includes an increase in total arable land during the period.
} 


\section{Organic nutrient management, integrated soil fertility management, and crop yields in SSA}

Sub-Saharan Africa is heterogeneous in soils, climate, agricultural potential, market access, and population density. These differences influence the types of organic nutrients that are technically feasible to produce, the types of crops that will benefit from such application, opportunity costs ${ }^{2}$ of land and labor, and cost of acquiring mineral fertilizers. In short, the incentives for producing and using specific nutrient inputs vary markedly across the continent. The ISFM paradigm acknowledges the need for both organic and mineral inputs to sustain soil health and crop production due to positive interactions and complementarities between them (Buresh et al., 1997; Vanlauwe et al., 2002a).

Among the most promising organically based soil nutrient practices are: animal manure, compost, incorporation of crop residues, natural fallowing, improved fallows, relay or intercropping of legumes (and dual purpose legumes), and biomass transfer. These are briefly described in Table 1. While we focus on soil nutrient management practices, there are a host of other management practices that are vitally important to overall soil fertility, including soil conservation and tillage techniques, weed management practices, and cropping strategies themselves.

Initially, organic resources were merely seen as sources of nutrients, mainly nitrogen $(\mathrm{N})$. A substantial amount of research was done on quantifying the availability of $\mathrm{N}$ from organic resources as influenced by their resource quality and the physical environment (Palm et al., 2001, for example). More recently, other contributions of organics extending beyond fertilizer substitution have been emphasized in research, such as the provision of other macro and micro-nutrients, reduction of phosphorus sorption capacity, increase in carbon/organic matter, reduction of soil borne pest and disease spectra in rotations, and improvement of soil moisture status (Vanlauwe et al., 2002a).

There are some key differences in the way that the organic systems contribute to soil fertility. Those systems using nitrogen-fixing species add large amounts of nitrogen without withdrawing it from soils. Organic sources will differ in terms of nutrient content, mineralization processes (in which the nutrients in the organic compounds can become available to the crop), and the provision of other soil fertility benefits (e.g. weed reduction). Management aspects also influence the effectiveness of organics. The growing of legumes in situ (rather than transferring biomass from outside) can provide other benefits to crops through rotation effects (e.g. reducing weeds) and through water infiltration effects (from the root systems).

It has been acknowledged that organic and mineral inputs cannot be substituted entirely by one another and are both required for sustainable crop production (Buresh et al., 1997; Vanlauwe et al., 2002a). This is due to (1) practical reasonsfertilizer or organic resources alone may not provide sufficient amounts or may be unsuitable for alleviating specific constraints to crop growth (Sanchez and Jama,

\footnotetext{
${ }^{2}$ High opportunity costs meaning that there are alternative highly valued uses for land and labor.
} 
Table 1

Description of main organic soil fertility practices in Sub-Saharan Africa

\begin{tabular}{|c|c|}
\hline Organic practice & Description \\
\hline Animal manure & $\begin{array}{l}\text { The spread of solid and liquid excrement from animals, mainly cattle. } \\
\text { Intensified livestock production systems involve the collection of manure } \\
\text { in stalls or pens, while the more extensive systems involve direct depo- } \\
\text { sition of manure by grazing animals. }\end{array}$ \\
\hline Compost & $\begin{array}{l}\text { The collection and distribution of a range of organic compounds that } \\
\text { may include soil, animal waste, plant material, food waste, and even } \\
\text { doses of mineral fertilizers. Prior to application of compost onto the field, } \\
\text { there is a period of incubation to decompose materials. }\end{array}$ \\
\hline Crop residues & $\begin{array}{l}\text { The in situ utilization of crop residues. The utilization may be in the form } \\
\text { of leaving residues on the surface or by cutting, chopping, and incorpor- } \\
\text { ation of crop residues into the soil. This operation is often done at the } \\
\text { time of land preparation for the following season. }\end{array}$ \\
\hline Natural fallow & $\begin{array}{l}\text { Withdrawal of land from cultivation for a period of time to permit natu- } \\
\text { ral vegetation to grow on the plot. The breaking of the crop cycle and } \\
\text { lead to regeneration and the fallows can also recycle nutrients. }\end{array}$ \\
\hline Improved fallow & $\begin{array}{l}\text { The purposeful planting of a woody or herbaceous plant to grow on a } \\
\text { plot for a period of time. In addition to benefits of natural fallows, } \\
\text { improved fallows can achieve equal impacts of natural fallows in shorter } \\
\text { time periods because of purposeful selection of plants, such as those that } \\
\text { fix atmospheric nitrogen. }\end{array}$ \\
\hline Intercropping systems & $\begin{array}{l}\text { Nutrient sources are integrated with crops in both time and space. The } \\
\text { organic source may be a permanent feature on the plot such as with alley } \\
\text { farming or scattered trees or may also be annual legumes. Intercrops are } \\
\text { normally carefully planted, but trees in certain parkland systems (e.g. } \\
\text { Faidherbia albida) are naturally growing. }\end{array}$ \\
\hline Relay systems & $\begin{array}{l}\text { Relay systems are similar in sharing space with the crop, but the organic } \\
\text { source is planted at a different time than the crop and the timing of their } \\
\text { primary growth period may differ. }\end{array}$ \\
\hline Dual purpose legumes & $\begin{array}{l}\text { These may be grown in intercrops or rotations with cereals. They thus } \\
\text { maintain the features described above except that they also produce a } \\
\text { second major product such as a grain for human consumption. }\end{array}$ \\
\hline Biomass transfer & $\begin{array}{l}\text { The transport and application of green organic material from its ex situ } \\
\text { site to the cropping area. The organic source may be purposefully or nat- } \\
\text { urally grown. }\end{array}$ \\
\hline
\end{tabular}

2002), (2) the potential for added benefits created through positive interactions between organic and mineral inputs in the short-term and (3) the various roles each of these inputs play in the longer term. One key complementarity is that organic resources enhance the soil organic matter status and the functions it supports, while mineral inputs can be targeted to key limiting nutrients. Several attempts to quantify the size of added benefits and the mechanisms creating those have been made. Vanlauwe et al. (2002b) reported positive interactions between urea and use of stover and other organic applications while Nhamo (2001) observed added benefits from manure and ammonium nitrate combinations.

Although the above list of observed positive interactions between organic and mineral inputs is not exhaustive, very often these inputs are demonstrated to have 
only additive effects. ${ }^{3}$ But because of declining marginal increases from one single type of input, the additive effects are often superior in terms of overall yields and net financial returns, as shown by Bationo et al. (1998) for millet in Niger and Rommelse (2001) on maize in Kenya. Negative interactions are hardly ever observed.

In summary, there is considerable evidence demonstrating the important contributions of organic matter alone to agricultural crop yields. There is more limited, but still significant, evidence attesting to the positive short and long term impacts of ISFM technologies integrating organic and mineral nutrient sources. Increasing economic analysis of these systems and evidence from farmer-managed practices are noted in the following section. One caveat is that nearly all agronomic research on ISFM has taken place on cereal crops. Yet, much organic and mineral fertilizer use by smallholders is directed towards higher value crops for which the effects of organics and ISFM remain under-researched.

\section{Actual nutrient management practices of African farmers ${ }^{4}$}

It comes as little surprise that farmer use of organic inputs is often high in farming systems that are intensifying. Farmers appreciate the yield impacts of organic systems but also the economic complementarities between organic and mineral inputs. The two approaches to soil fertility management rely on different household resources, with fertilizer requiring financial capital and organics mainly requiring labor and land. Inflexible packaging in $50 \mathrm{~kg}$ bags constrains fertilizer purchase by farmers with limited resources. Comparatively, organics can be cheaply and conveniently produced on farm. In terms of quantities available, imported mineral fertilizers are in theory plentiful if the demand is there. On the other hand, production of organics is limited by available land and therefore supplying sufficient amounts for one's farm, let alone for sale in the market, can prove challenging.

Recent studies have shown a host of nutrient management practices undertaken by smallholder African farmers (Place et al., 2002b). The use of animal manure and legume intercropping are well-established practices, but others such as composting and agroforestry are relatively new. In Kenya, Omiti et al. (1999) found that between $86 \%$ and $91 \%$ of farmers used manure in semi-arid and semi-humid zones east of Nairobi. Compost was adopted by about $40 \%$ of farmers in the more favorable parts of these zones, but by relatively few in the more arid sites. In the more humid western highlands, Place et al. (2002a) found that $70 \%$ of households used manure and $41 \%$ used compost. Additionally, over $20 \%$ of farmers were using improved tree fallows and biomass transfer, two agroforestry systems recently promoted in the study area. Similarly, Clay et al. (2002) found $49 \%$ of Rwandan

\footnotetext{
${ }^{3}$ Additive does not imply perfect substitutability for fertility-enhancing processes.

${ }^{4}$ This section largely summarizes results reported in detail in Barrett et al. (2002b), drawing especially heavily on the chapter by Place et al. (2002b).
} 
farmers' plots received organic nutrient inputs and Gambara et al. (2002) found legume rotations and green manure systems practiced in 48 and 23 percent of focal extension areas in Zimbabwe. There are also cases of high adoption rates of alley farming in areas of Nigeria (Adesina and Chinau, 2002) and of Mucuna fallows in Benin and Cameroon (Manyong and Houndekon, 2000). While the relative adoption rates between organic and mineral nutrients vary by location, the incidence of organic practices (especially natural fallowing and animal manure) often outpaces the use of mineral fertilizers. The most striking case may be Rwanda where only $2 \%$ of plots received mineral fertilizer.

There is less information available on the quantities of organic nutrients applied, but it is well recognized that they often face increasing opportunity costs and therefore the amounts produced and applied are limited. Opportunity costs can be high in terms of labor when the timing of operations coincides with other vital activities and in terms of land when increased organic nutrient production means taking more valuable land out of production (see Omiti et al., 1999 and Williams, 1999 for animal manure). Recent research has uncovered numerous farmer innovations to reduce labor and land inputs (Waddington, 1999; Tarawali et al., 2002; Misiko and Ramisch, unpublished data).

In terms of profitability, evidence of positive returns is reported for improved fallows and biomass transfer (Place et al., 2002a) and manure (Mekuria and Waddington, 2002). Positive returns are often found for mineral fertilizer inputs (Kelly et al., 2002; Shapiro and Sanders (2002) and for integrated mineral-organic systems (Place et al., 2002a; Mekuria and Waddington, 2002). For example, the integration of manure and fertilizer on maize in Zimbabwe resulted in a return to labor of about $\$ 1.35$ per day, while the best single fertilizer or manure treatment yielded only $\$ 0.25$ (Mekuria and Waddington, 2002). Returns to integrated biomass transfer and rock phosphate systems on kales and tomatoes in Kenya showed returns to labor of between $\$ 2.14$ to $\$ 2.68$ as compared to a best return of $\$ 1.68$ when only one of the options were used (Place et al., 2002a). While more economic analyses of farmer-managed ISFM systems are needed, existing evidence suggests that organic or ISFM systems may be remunerative where purchased fertilizer alone remains unattractive.

Kenyan farmers often incorporate more than one nutrient source on their farms. Freeman and Coe (2002) found that $37 \%$ of farmers in the relatively drier zones of Kenya used both organic and mineral fertilizers. A further $10 \%$ were using more than one organic source but without mineral fertilizer. In the western Kenyan highlands, more than two-thirds of farmers using mineral fertilizer also used animal manure (Place et al., 2002a). Murithi (1998) found multiple sources of nutrients used on a variety of crops in Central Kenya. This is generally true of areas where livestock are important and markets for fertilizer exist. There is little integration of organics and mineral fertilizer in Uganda, for example, because fertilizer availability (if not demand) is poor. There are also selected cases of green manure/mineral fertilizer systems such as in Malawi, where farmers use both pigeon pea intercrops and fertilizer (Peters, 2002). 
Both organic and mineral fertilizer use responds positively to improved output markets and crop prices (Murithi, 1998; Freeman and Coe, 2002). Animal manure is commonly used on higher-value commodities such as potato, coffee, and vegetables (Freeman and Coe, 2002; Shapiro and Sanders, 2002). As with manure, farmers have shifted promising innovations using new green organic systems (or integrations of organic and mineral fertilizers) onto higher-value commodities such as vegetables (Place et al., 2002a). Organic sources that provide a dual benefit (e.g. food) are even more preferred by farmers.

Organic nutrient systems are commonly more affordable to cash-strapped households than fertilizer options. This is critical, because many studies have found that poor farmers' inability to access mineral fertilizers has adverse consequences on soil fertility and incomes (Soule and Shepherd, 2000). Furthermore, because livestock ownership is positively related to household incomes, wealthier households are more likely to use manure than poorer ones (Mekuria and Waddington, 2002). In contrast, poorer households use agroforestry-based nutrient systems and compost in Western Kenya at the same proportion as wealthier ones (Place et al., 2002a). However, there is concern that as land sizes continue to shrink, identifying niches for producing any type of organic nutrient source will become increasingly difficult.

In summary, emerging evidence from across Africa points to widespread use of organic inputs, often in conjunction with less widely used mineral fertilizers. The profitability of alternative nutrient input sources depends not only on yield gains but also on market conditions, as underscored by generally greater use on highervalued commodities. However, the direct empirical evidence on ISFM profitability is thin, creating a serious research gap.

\section{Implications of organic or IFSM nutrient systems for input markets}

We now explore the potential for market growth around organic nutrient inputs themselves and secondly the potential for the use of organic nutrients to catalyze traditional input markets. Markets for organic nutrient inputs can be broken down into trade in the nutrient source itself, trade in the germplasm that produces the organic nutrients, and trade in the required complementary inputs such as labor. The development of markets (formal or informal) for organic inputs in Africa has been shaped, constrained, and geographically limited by the extreme variability in the supply of organic resources and their relative bulkiness (low nutrient value per unit mass).

The supply of organic resources that are potentially important contributors to agriculture - manure, crop residues, and other plant biomass - is both seasonally and spatially variable. Spatial variability can be observed as gradients of input use at the level of individual farms, inter-farm variability based on differential resource endowments, and variability at the landscape and higher levels due to agro-climatic differences. Seasonal variability affects the abundance of key materials: crop residues are available in vast quantities only at harvest or as pre-harvest thinnings, 
manure is more abundant during rainy seasons but more likely to be dispersed by grazing across the landscape. Temporal variability is also seen in the quality of materials. The nitrogen content of manure or harvested organic materials declines rapidly with the passage of time, as does the overall nutrient value of leaves if they are allowed to mature or senesce. Inter-seasonal storage of organic soil nutrient amendments is therefore impractical.

The second factor, bulkiness, is a key constraint on the transport of organic materials. The much observed 'ring management' of many Sahelian farming systems (cf. Prudencio, 1993) reflects the decline in input application rates as fields become more distant from the nutrient source (typically the homestead at the center of the ring). Comparing yield benefits from manure application with the labor involved in transporting it, Schleich (1986) found that for a community in Côte d'Ivoire, ox carts were profitable up to a distance of $1 \mathrm{~km}$, whereas transport on foot was not profitable at any distance. Since animal-powered transport can increase the efficiency of labor-intensive transport activities to the point of profitability, dynamic community-level markets for the exchange of draft power have been reported for transporting manure (Mazzucato and Niemeijer, 2001 in Burkina Faso; Ramisch, 1999 in Mali).

Because transportation is an important constraint, there is a strong incentive to produce organic inputs in situ (such as companion planting of legumes with cereal crops or corralling of livestock on cropland before planting). Throughout much of West Africa, the manure of large semi-sedentary and transhumant herds is a key resource for settled farmers (Landais and Lhoste, 1990; McIntire and Gryseels, 1987), and such manure is often the catalyst for inserting pastoralists into the exchange networks of a settled community (Ramisch, 1999). Where market access provides a vent for surplus crop production, exchanges of 'excess' manure or compost between settled farmers are also common, either for cash (Tiffen et al., 1994) or labor for other activities (Ramisch, 1999).

At issue are not just markets for soil amendments themselves, but also the materials for in situ production of organic inputs. Farmer willingness to pay for germplasm for green manure is low because of free distributions by projects, high quantity requirements, and an ability to harvest and reuse seed for most green manure plants. Where intensification of leguminous grains is linked to grain market development, farmers have shown greater willingness to invest in improved seeds (Jones et al., 2002). Species with multiple benefits, such as dual-purpose soybeans or cowpeas are more likely to be adopted than those purely for soil improvement. ${ }^{5}$ On the other hand, the proliferation of markets for Mucuna seeds in West Africa was related to its perceived ability to suppress the noxious grass Imperata. ${ }^{6}$

\footnotetext{
${ }^{5}$ Here is where another interaction with markets occurs because markets for the grain product may influence more the growing of the legume than the soil fertility benefit. In the case of plants whose leaves can provide soil fertility and fodder benefits, improved markets for fodder may reduce the use of green biomass for soil fertility.

${ }^{6}$ It should be noted however, that at earlier stages of these dissemination processes, NGOs and their project often play key roles in fostering markets.
} 
But within 2-3 years this weed was controlled and Mucuna was no longer marketed (Houndékon et al., 1998). The anecdotal evidence that exists for the development of seed markets for legume cover crops suggests that social networks are paramount in spreading both information and the small amounts of seed that become periodically available to members outside the group (Misiko, 2000).

Widespread adoption of the ISFM paradigm depends also on the availability of traditional seed and mineral fertilizer inputs. Will the use of organics encourage growth in traditional input markets, particularly for fertilizer or improved seed? There are various possible pathways: (1) generation of income that increases farmer purchasing power to directly buy fertilizer and improved seed; (2) increased income that enables farmers to invest more in cash crops which themselves stimulate the use of inputs; (3) synergistic benefits arising from integrating organic and mineral fertilizers at the plot or farm level; (4) enhanced learning of soil fertility management through the use of organics; (5) increased returns from improved seed once soil fertility constraints are ameliorated through ISFM; and (6) economies of scope in trader handling of inputs, where increased demand for organics reduces unit costs throughout input marketing chains.

The evidence presented above indicates that indeed organic nutrient systems can increase yields and profits, even in semi-subsistence systems where purchased fertilizers remain unattractive, and that there appear to be important biochemical synergies achievable from integrating organic and mineral fertilizers. So there indeed appears some prospect for increased use of organics to stimulate traditional agricultural input markets through pathways (1)-(3). The magnitude of these effects has not been explicitly researched to date, but it is likely to be modest. In some cases, the amount of additional income generated is low because of limited application of organic manure (Place et al., 2002c). Moreover, there has been little research on whether such increases translate into increased investment in agriculture, particularly in adoption of improved seed or mineral fertilizer. Soule and Shepherd (2000) show that very poor farmers in western Kenya are hardly able to make any investments in agriculture. And while there tends to be a positive relationship between the use of organics and cultivation of higher-value crops, the direction of causality in that relation is unclear. On-farm investment is limited not just by incomes or crop mix, but also by the institutional and physical infrastructure in a region, land tenure, alternative (non-farm) investments, and the information available on different technologies and market opportunities (Barrett et al., 2002a). The evidence for synergistic effects is mainly from researcher-managed trials.

To our knowledge, there is little direct evidence on pathways (4) or (5). Certainly, most recent agricultural development projects that include promotion of organic nutrient systems emphasize training on principles of soil fertility management more than in the past. But the effects of these efforts are not well documented. Similarly, while it is well known that use of improved seed is linked to use of fertilizer, the role of organic nutrient systems in stimulating improved seed use is again not well documented. 
The literature on agricultural marketing systems in Africa indirectly supports the hypothesis of pathway (6), as it suggests the existence of economies of scope in trading activities, with intermediaries commonly specializing more according to function (e.g., crop collection, input distribution) than by product, apparently because it pays for traders to buy or sell a range of products (Barrett, 1997; Omamo and Mose, 2001; Kherallah et al., 2002). The hypothesis that expansion of organic input use through market purchases of seed for improved fallows, manure, etc. stimulates expansion of input markets in traditional inputs merits attention. However, the participation of non-profit organizations in organic material supply distorts the development of this pathway.

In the absence of studies that address particular causal chains, we must rely on studies that have more generally described the patterns of use of alternative soil fertility management practices. These indicate mixed results on the catalytic ability of organic nutrients to enhance traditional input markets. A recent study of improved fallow and biomass transfer systems in western Kenya found that they were being used by 30-45 percent of those households who were not using fertilizer or manure (Place et al., 2002c). However, they have not yet spurred an increase in the use of fertilizer. Likewise, some studies have suggested that in cash cropping systems organic inputs only replace fertilizer when fertilizer supply becomes problematic (Bosma et al., 1996; Mortimore, 1998). Raynaut (1997) found evidence linking increased availability of mineral fertilizers for cash crops to increased use of organic nutrients on food crops. In Niger, Abdoulaye and Lowenberg-DeBoer (2000) showed that patterns of intensification exhibit a pattern of graduation from manure to mineral fertilizer use. Clearly, there remain information gaps as to how much and under which conditions farmers perceive different options as complements or substitutes, to what extent benefits from organic systems are generating further agricultural investment, and how new learning processes on soil fertility management are creating new demands for integrated nutrient packages. At the margin, increasing use of organic inputs by farmers practicing ISFM may stimulate traditional agricultural input markets, but in most of Africa the binding constraints on input market growth seem unlikely to be relieved by this development.

\section{Summary: enhancing ISFM's contribution}

ISFM practices are thriving in agricultural research and development projects with the use of organic inputs increasing, both on a stand-alone basis and in conjunction with mineral fertilizers. Much of this initiative is due to farmer innovation and adaptation, often in response to macroeconomic and sectoral reforms that have driven up real fertilizer prices throughout the continent. Organic systems have been found to complement fertilizers in many ways, both in a biophysical sense (enhancing soil health beyond nutrients alone) and in a socio-economic sense (requiring different types of household resources). Some organic systems are performing well on their own and in integrated systems, as measured by yields and profits. Like mineral fertilizer, there appears to be more interest in, and impact 
from, the use of organics and integrated systems on higher value crops. Because of their low cash requirements, some organic-based systems are reaching poorer households that otherwise are scarcely using any fertilizer.

But there are limits to the amounts of organics that can be produced on-farm, particularly where labor or land constraints are reached. There remains insufficient evidence as to whether increased use of organic inputs is spurring increased overall use of nutrient inputs. While biophysical research in integrated soil fertility management is progressing rapidly, more research is needed on farmers' practices, including their innovations and integration of individual components. There is also an urgent need to extend both bodies of research to higher value crops and whole farm analyses, including farmers' alternative investment options in non-farm activities.

Markets for organic biomass are likely to remain highly localized because transporting costs increase steeply with distance and because supplies are highly variable both temporally and spatially. Lively markets have developed where knowledge of organics and their benefits have existed for a long time, as is the case for animal manure. Markets for much more recently introduced technologies, such as green manure, do not yet exist to any significant degree. Markets for green manure germplasm have developed in response to demand from projects and from farmers when the introduced plant yields benefits beyond soil nutrient replenishment, such as feed or food products. There is no direct evidence of the effect of organics or ISFM on markets for fertilizer and seed. Our analysis of indirect evidence suggests that this link is potentially important but in practice not yet widely realized.

In order to contribute ultimately to wider adoption of ISFM practices and increased benefits, a few steps can be highlighted. First, there is still a need to develop more attractive options, components and integrated strategies for small farmers of which improved germplasm is an integral part. Second, because ISFM practices are knowledge intensive, a major challenge is to identify scaling up processes that are both effective and not too costly in terms of information provision and technical support. Third, there must be major efforts to make agricultural commercialization more attractive to small farmers (Barrett et al., 2002c). Low rates of market participation are leading correlates of both poverty and the absence of sustainable agricultural intensification through increased investment in the land (Barrett and Carter, 1999; Reardon et al., 1999). The promotion of highvalue agricultural enterprises is one policy direction that is likely to generate increased income and investment in ISFM.

To conclude, much remains to be done, in terms of research and development, if the emergent ISFM paradigm is to increase Africa's miniscule rates of mineral fertilizer application and stimulate agricultural productivity growth. The task is made all the more pressing by economic policy reforms that have caused a sharp drop in fertilizer use by small farmers in many areas. 


\section{Acknowledgements}

We thank Doug Brown, John Lynam and the guest editors for helpful comments on an earlier draft. Any remaining errors are entirely our responsibility.

\section{References}

Abdoulaye, T., Lowenberg-DeBoer, J., 2000. Intensification of Sahelian farming systems: evidence from Niger. Agricultural Systems 64, 67-81.

Adesina, A., Chianu, A., 2002. Farmers' use and adaptation of alley farming in Nigeria. In Barrett et al., 2002b, pp. 51-64.

Barrett, C.B., 1997. Food marketing liberalization and trader entry: evidence from Madagascar. World Development 25, 763-777.

Barrett, C.B., Carter, M.R., 1999. Microeconomically coherent agricultural policy reform in Africa. In: Paulson, J. (Ed.), The Reform Experiences. African Economies in Transition, vol. 2. Macmillan, London.

Barrett, C.B., Place, F., Aboud, A., Brown, D.R., 2002a. The challenge of stimulating adoption of improved natural resource management practice in African Agriculture. In Barrett et al. 2002b, pp. $1-22$.

Barrett, C.B., Place, F., Abdillahi, A. (Eds.), 2002b. Natural Resources Management in African Agriculture: Understanding and Improving Current Practices. CABI, Wallingford, UK.

Barrett, C.B., Lynam, J., Place, F., Reardon, T., Aboud, A.A., 2002c. Towards improved natural resource management in African agriculture. In Barrett et al., 2002b, pp. 287-296.

Bationo, A., Lompo, F., Koala, S., 1998. Research on nutrient flows and balances in West Africa: Stateof-the-art. Agriculture. Ecosystems and Environment 71 (1-3), 19-35.

Bosma, R., Bengaly, K., Traore, M., Roeleveld, A., 1996. L'elevage en voie d'intensification: Synthese de la recherche sur les ruminants dans les exploitations agricoles mixtes au Mali-Sud. Royal Institute of the Tropics (KIT), Amsterdam.

Buresh R.J., Sanchez, P.A., Calhoun, F. (Eds.), 1997. Replenishing soil fertility in Africa. SSSA Special Publication Number 51, Soil Science Society of America. Madison, Wisconsin, USA.

Clay, D.C., Kelly, V., Mpyisi, E., Reardon, T., 2002. Input use and conservation investments among farm households in Rwanda: patterns and determinants. In Barrett et al., 2002b, pp. 103-114.

De Jager, A., Kariuku, I., Matiri, M., Odendo, M., Wanyama, J.M., 1998. Monitoring nutrient flows and economic performance in African farming systems (NUTMON). IV. Linking nutrient balances and economic performance in three districts in Kenya. Agriculture, Ecosystems and Environment 71 $(1-3), 81-92$.

FAOSTAT, 2002. Food and Agricultural Statistical Database. www.fao.org/waicent/portal/statistics_ en.asp

Freeman, H.A., Coe, R., 2002. Smallholder farmers' use of integrated nutrient-management strategies: patterns and possibilities in Machakos District of Eastern Kenya. In Barrett et al., 2002b, pp. 143154.

Gambara, P., Machemedze, T., Mwenye, D., 2000. Chihota Soil Fertility Project, Annual Report 1998 to 1999. Unpublished report, AGRITEX, Marondera Zimbabwe.

Henao, J., Baanante, C., 2001. Nutrient depletion in the agricultural soils of Africa. In: Pinstrup-Andersen, P., Pandya-Lorch, R. (Eds.), The Unfinished Agenda: Overcoming Hunger, Poverty, and Environmental Degradation. IFPRI, Washington, pp. 159-163.

Houndékon, V., Manyong, V.M., Gogan, C.A., Versteeg, M., 1998. Déterminants de l'adoption de Mucuna dans le département du Mono au Bénin. In: Buckles, D., Etèka, A., Osiname, O., Galiba, M., Galiano, G. (Eds.), Cover Crops in West Africa: Contributing to Sustainable Agriculture. IDRC, Ottawa, pp. 45-54.

Jones, R.B., Freeman, H.A., Lo Monaco, G., 2002. Improving the access of small farmers in eastern and southern Africa to global pigeonpea markets. AgREN Network Paper No. 120. ODI, London. 
Kelly, V., Sylla, M.L., Galiba, M., Weight, D., 2002. Synergies between natural resource management practices and fertilizer technologies: lessons from Mali. In Barrett et al., 2002b, pp. 193-204.

Kherallah, M., Delgado, C., Gabre-Madhin, E., Minot, N., Johnson, M., 2002. Reforming agricultural markets in Africa. . Johns Hopkins University Press, Baltimore.

Landais, E., Lhoste, P., 1990. L'association agriculture-élevage en afrique intertropicale: un mythe techniste confronté aux réalités du terrain. Cahiers des Sciences Humaines 26 (1-2), 217-235.

Manyong, V., Houndekon, V., 2000. Land tenurial systems and the adoption of mucuna planted fallows in the derived savannas of West Africa. CAPRi Working Paper Number 4, International Food Policy Research Institute, Washington, DC.

Mazzucato, V., Niemeijer, D., 2001. Overestimating land degradation, underestimating farmers in the Sahel. IIED Drylands Issue Paper \#101. International Institute for Environment and Development, London.

McIntire, J., Gryseels, G., 1987. Crop-livestock interactions in sub-Saharan Africa and their implications for farming systems research. Experimental Agriculture 23, 235-243.

Mekuria, M., Waddington, S.R., 2002. Initiatives to Encourage Farmer Adoption of Soil-fertility Technologies for Maize-based Cropping Systems in Southern Africa. In Barrett et al., 2002b, pp. 219234.

Misiko, M.T., 2000. The Potential of Community Institutions in Dissemination and Adoption of Agricultural Technologies in Emuhaya, Western Kenya. MA Thesis, University of Nairobi, Nairobi.

Mortimore, M., 1998. Roots in the African Dust: Sustaining the Drylands. Cambridge University Press, Cambridge, UK.

Murithi, F., 1998. Economic Evaluation of the Role of Livestock in Mixed Smallholder Farms of the Central Highlands of Kenya. Ph.D. Thesis, Department of Agriculture, University of Reading.

Nhamo, N., 2001. An evaluation of the efficacy of organic and inorganic fertilizer combinations in supplying nitrogen to crops. M Phil thesis, University of Zimbabwe, Harare, Zimbabwe.

Oldeman, L.R., Hakkeling, R., Sombroek, W.G., 1991. World map of the status of human-induced soil degradation: an explanatory note, 2nd revised edition. International Soil Reference and Information Centre, Wageningen.

Omamo, S.W., Mose, L.O., 2001. Fertilizer trade under market liberalization: preliminary evidence from Kenya. Food Policy 26 (1).

Omiti, J.M., Freeman, H.A., Kaguongo, W., Bett, C., 1999. Soil Fertility Maintenance in Eastern Kenya: Current Practices, Constraints, and Opportunities. CARMASAK Working Paper No. 1. KARI/ICRISAT, Kenya.

Palm, C.A., Gachengo, C.N., Delve, R.J., Cadisch, G., Giller, K.E., 2001. Organic inputs for soil fertility management in tropical agroecosystems: application of an organic resource database. Agriculture, Ecosystems and Environment 83, 27-42.

Peters, P., 2002. The limits of knowledge: securing livelihoods in a situation of resource scarcity. In Barrett et al., 2002b, pp. 35-50.

Place, F., Franzel, S., Dewolf, J., Rommelse, R., Kwesiga, F., Niang, A., Jama, B., 2002a. Agroforestry for soil fertility replenishment: evidence on adoption processes in Kenya and Zambia. In Barrett et al., 2002b, pp. 155-168.

Place, F., Swallow, B.M., Wangila, J.W., Barrett, C.B., 2002b. Lessons for natural resource management technology adoption and research. In Barrett et al., 2002b, pp. 275-286.

Place, F., Franzel, S., Noordin, Q., Jama, B., 2002c. Improved Fallows in Kenya: History, Farmer Practice, and Impacts. Paper presented at the IFPRI workshop on Successes in African Agriculture, June 10-12, 2002, Lusaka, Zambia.

Prudencio, C.Y., 1993. Ring management of soils and crops in the West African semi-arid tropics: The case of the Mossi farming system in Burkina Faso. Agriculture, Ecosystem and Environment 47, $237-264$.

Ramisch, J.J., 1999. The long dry season: Crop-livestock linkages in Southern Mali. IIED Drylands Issue Paper \#88, International Institute for Environment and Development, London.

Raynaut, C. (Ed.), 1997. Societies and Nature in the Sahel. Routledge, London.

Reardon, T., Barrett, C.B., Kelly, V., Savadogo, K., 1999. Policy reforms and sustainable agricultural intensification in Africa. Development Policy Review 17 (4), 293-313. 
Rommelse, R., 2001. Economic analyses of on-farm biomass transfer and improved fallow trials in western Kenya. Natural Resources Problems, Priorities and Policies Programme Working Paper 2001-2. International Centre for Research in Agroforestry, Nairobi.

Sanchez, P.A., Jama, B.A., 2002. Soil fertility replenishment takes off in East and Southern Africa. In: Vanlauwe, B., Diels, J., Sanginga, N., Merckx, R. (Eds.), Integrated Plant Nutrient Management in sub-Saharan Africa: from Concept to Practice. CABI, Wallingford, UK, pp. 23-45.

Schleich, K., 1986. Le fumier peut-il remplacer la jachère? Possibilité d'utilisation du fumier: exemple de la savane d'Afrique occidentale. Revue Elevage et Medecine Veterinaire des Pays Tropicaux 39 (1), $97-102$.

Shapiro, B.I., Sanders, J.H., 2002. Natural resource technologies for semi-arid regions of Sub-Saharan Africa. In Barrett et al, 2002b, pp. 155-168.

Soule, M., Shepherd, K.D., 2000. An ecological and economic analysis of phosphorus replenishment for Vihiga Division, western Kenya. Agricultural Systems 64, 83-98.

Stoorvogel, J., Smaling, E., 1990. Assessment of soil nutrient depletion in sub-Saharan Africa: 19832000. Report No. 28, vol. 1-4. Winand Staring Center, Wageningin, Netherlands.

Tarawali, G., Douthwaite, B., de Haan, N.C., Tarawali, S., 2002. Farmers as co-developers and adopters of green-manure cover crops in West and Central Africa. In Barrett et al., 2002b, pp. 65-76.

Tiffen, M., Mortimore, M., Gichuki, F., 1994. More People, Loss Erosion: Environmental recovery in Kenya. . John Wiley \& Sons, London.

Vanlauwe, B., Diels, J., Sanginga, N., Merckx, R., 2002a. Integrated Plant Nutrient Management in sub-Saharan Africa: From Concept to Practice. CABI, Wallingford, UK, (352 pp).

Vanlauwe, B., Aihou, K., Aman, S., Iwuafor, E.N.O., Tossah, B.K., Diels, J., Sanginga, N., Merckx, R., Deckers, S., 2002b. Maize yield as affected by organic inputs and urea in the West-African moist savanna. Agronomy Journal. In press.

Waddington, S., 1999. Some Promising Soil Fertility Technologies Being Developed Within SoilFertNet. In CIMMYT Risk Management for Maize Farmers in Drought-Prone Areas of Southern Africa: Proceedings of a workshop held at Kadoma Ranch, Zimbabwe, 1-3 October, 1997. CIMMYT, Mexico, D.F.

Williams, T., 1999. Factors influencing manure application by farmers in semi-arid West Africa. Nutrient Cycling in Agroecosystems 55, 15-22. 